\title{
The Politics of \\ Representing Disability
}

Exploring News Coverage of

the Americans with

Disabilities Act and the

National Disability Insurance

Scheme

\author{
Shawn Burns ${ }^{1}$ \\ Beth Haller ${ }^{2}$
}

\begin{abstract}
Twenty-five years on from the implementation of the Americans with Disabilities Act (ADA), media representation of people with disability has become even more significant. More recently, the implementation of the National Disability Insurance Scheme (NDIS) in Australia has placed people with disability, and the issues they face, at the forefront of political discourse. This study looks at the media coverage of the ADA and the NDIS as significant social and political landmarks in their respective countries. Using content analysis, this article explores how media representations of people with disability are substantial factors within social reform, societal inclusion and equal rights. Because of numerous barriers to participation in many countries, people with disability may only be known to the larger society through media representations. Disability rights-focused news coverage is important to a society's awareness of disability issues, so this research contributes to a better understanding of how political issues regarding people with disabilities play out in two countries' news media.
\end{abstract}

\section{Keywords}

Americans with Disabilities Act, National Disability Insurance Scheme, disability rights laws, political discourse, media representations, society inclusion of people with disability

${ }^{1}$ Journalism Lecturer, University of Wollongong, Wollongong, NSW, Australia.

${ }^{2}$ Professor of Journalism/New Media, Towson University in Maryland, USA.

Corresponding author:

Shawn Burns, Journalism Lecturer, University of Wollongong, Wollongong, NSW,

Australia.E-mail: shawn@uow.edu.au 



\section{Introduction}

Twenty-five years on from the implementation of the Americans with Disabilities Act (ADA), there is cause for reflection on its successes and failures. The ADA had, at its core, the desire to ensure people with disability are included and recognized as part of the greater community. Likewise, the implementation of the National Disability Insurance Scheme (NDIS) in Australia has placed people with disability, and the issues they face, at the forefront of political discourse. This article explores how media representation of people with disability is a factor in achieving social reform and how, as the International Labour Organization (ILO) states, portraying 'women and men with disabilities with dignity and respect in the media can help promote more inclusive and tolerant societies' $(2015$, p. 7$)$.

Politics is often claimed to be the art of looking like you are doing something while determinedly doing nothing. As 'gatekeepers', the news media have a role to play in holding politicians and political operatives accountable. They also have the capacity to frame issues, and to set an agenda (McCombs \& Shaw, 1972). Journalists are challenged to find a strong 'angle' and, in doing so, they choose what to put in and leave out of a story, what story elements deserve more or less attention and how those elements are to be framed. The day-to-day processes of journalism, particularly news journalism, require journalists to be decision makers, and to make 'judgements about to what extent their work may impact on people' (Burns, 2011, p. 44). Croteau and Hoynes concur:

News is the product of a social process through which the media personnel make decisions about what is newsworthy and what is not, about who is important and who is not, about what views are to be included and what views are to be dismissed. (2003, p. 135)

McCombs reports that the choice and frame of a story are 'powerful agenda setting roles and awesome responsibilities' (1992, pp. 813-824). However, consideration must be given to the multiple hands, and iterations, a news story may pass through before publication. While there is mounting evidence to suggest the days of the subeditor are limited, and journalists/reporters are far more likely to be the sole contributor to a published item in the digital age, it is still reasonable to contend the final shape and placement of a news story is somewhat out of the control of journalists. 'Editors and sub-editors wield considerable power in the final framing of a published or broadcast story' (Burns, 2011, p. 55). The 'gatekeeping process' (Tanner, 1990) allows for 'journalists to have, at one end of the scale, stories published unchanged and, conversely, stories not published at all' (Burns, 2011, p. 55).

People with disabilities confront barriers that prevent them from being full and active members of society. Twenty-five years after the ADA became law in the United States and in an era where the NDIS is being rolled out in Australia, people with disabilities continue to face physical and figurative barriers. The news media is well placed to highlight these barriers and, in doing so, provide impetus for change. Gitlin states, 'The mass media are, to say the least, a significant social 
force in the forming and delimiting of public assumptions, attitudes, and moodsof ideology, in short' (1980, p. 9).

\section{The Americans with Disabilities Act}

According to Gusfield (1981), not all groups have the same power, influence and authority to define social problems. A group must truly own a problem to push it into the public sphere. For example, in the USA, disability organizations and disability activists began to 'own' the problem of full civil rights for people with disabilities in the late 1960s. By the 1970s, such ownership led to the develop- ment of the first major US disability rights law, the Rehabilitation Act of 1973, which made discrimination against people with disabilities illegal at institutions that received federal money. However, the US government had not truly embraced disability discrimination as a public problem, so disability activists held a number of protests across the nation about the lack of enforcement guidelines for the Rehab Act (Shapiro, 1994). Activist Mike Auberger highlighted the disability community's point: "The preamble of the Constitution does not say: "We the able- bodied people." It says: "We the people", (Collins, 2015, p. 53). It was not until the ADA of 1990, that this issue entered the consciousness of the whole of the US society.

The ADA provides broad civil rights to the disability community and mechanisms to fight discrimination against disabled people. The US Department of Justice (US DOJ), which enforces parts of the ADA, summarizes the law this way:

The ADA prohibits discrimination and ensures equal opportunity for persons with disabilities in employment, state and local government services, public accommodations, commercial facilities, and transportation. It also mandates the establishment of Telecommunications Devices for the Deaf (TDD)/telephone relay services. (US DOJ website, 2010b)

But for numerous reasons, the news media did not provide much coverage of the law, which in 2015 is seen as a groundbreaking disability rights legislation around the world (Rosenthal \& Kanter, 2002).

Gusfield explains that a component of the culture of public problems is mass media (1981). Media help construct the 'reality' of a public problem. In the case of the ADA, news media had only a little knowledge of disability rights when disability activists were lobbying for the ADA. "This bill seemed to come out of nowhere!" said New York Times reporter Steven A. Holmes when the ADA had passed the Senate back in 1989' (Johnson, 1998). So, journalists had to begin to develop some news sources within the disability community. However, past research on news sources illustrates that news media prefer sources from government and other elite sources, rather than grass-roots activists like those in the US disability rights movement.

Research by Tichenor, Donohue and Olien (1980) found in news stories about conflict that the power elite helps form the media's position, so the news media 
end up reinforcing the outlook of the dominant power in the community. In conflict situations, the press contributes to either a widening or narrowing of differences in knowledge within the system. Olien, Tichenor and Donohue (1989) again confirmed that the media lean in favour of the status quo and the 'mainstream' when covering public protests. That study found the media are watchdogs on behalf of the mainstream groups. 'Media report social movements as a rule in the guise of watchdogs, while actually performing as "guard dogs" for the mainstream interests' (Olien et al., 1989, p. 24).

News about disability laws also deals with a social group that had been traditionally marginalized and a social issue that had not received much press attention in the past. Typically, social issues take up less space in newspapers than other types of news. Ryan and Owen (1976) found that only 8.8 per cent of US metropolitan daily newspapers' news holes were devoted to social issues, such as, health, housing, education, crime-law, poverty-welfare, ecology, mass transit, racism-sexism and drug abuse. With even more unfortunate implications for disability coverage, Ryan and Owen found in a follow-up study (1977) that coverage of social issues contained more errors than general coverage. The accuracy data indicated that the most common errors were subjective, those in which the news source and the reporter may differ on how the information should have been treated. Although this is older research, it still has implications for the news coverage of disability issues because Clogston (1990) showed how in the past, the media reported on disability as a medical or welfare problem.

So, when the news media initially covered the US Congress passing the ADA in 1990, they took on the language of the law, which had been crafted by the disability rights' lobbyists (Haller, 1995). However, disability activists were so upset by the past inaccurate, stigma-inducing news coverage of disability, they decided the law was all they needed, not the media attention. Into that vacuum stepped news sources who were against the ADA because they saw it as a financial burden - mostly the business community and local governments (Haller, 1999). Journalist Joe Shapiro explained that disability lobbyists for the ADA made little use of the media to push their ideas because they thought the media stories would perpetuate stereotypes and hinder the public's understanding of disability rights. Shapiro called this a stealth tactic that 'defied conventional wisdom' (1993), and many argue that it set back the public understanding and even the enforcement of the ADA for many years.

Mary Johnson, long-time editor of the US disability rights magazine The Disability Rag (later named The Ragged Edge in its online version), was highly critical of the 'no media' decision:

The decision not to seek media attention for this major civil rights bill was a conscious one, according to Pat Wright of the Disability Rights Education and Defense Fund, a chief lobbyist for the law, who told U.S. News \& World Report's Joseph P. Shapiro that, had the disability rights movement sought press attention, 'we would have been forced to spend half our time trying to teach reporters what's wrong with their stereotypes of people with disabilities'. The risk, they felt, didn't seem worth it. (Johnson, 1998) 
Writing 8 years after the ADA passed, Johnson says the 'decision for silence now seems to have created its own disastrous consequences'.

Haller's research on the news media coverage of the ADA confirmed this lacklustre interest in the 'disability side' of the story of the legislation $(1995,1996$, 1999). In analyzing news stories about the ADA in the early 1990s, she showed how the perspective of the US business community that made it into the ADA stories may have cast a new stereotype of people with disabilities in US cultural narratives: that people with disabilities cost society money. The voice of the business community reflects the paradigm of capitalism in the United States, and journalists ply their trade in this society.

Haller found that a 'balanced' style of sourcing stories about disability issues weakened the 'disability side' of the story (1996). On the one hand, the news media's reliance on federal government sources worked in the favour of the 'disability side' of the ADA story because it was the same as the government side of the story. Disability activists and lobbyists basically wrote most of the federal legislation. On the other hand, in their adversarial role, journalists did challenge the federal government's side of the story by going to business and local government sources in the news stories. The business community and local governments, fearing the financial ramifications of the ADA, supplied information to the media with an alternative frame for the Act - that the ADA would be costly to them (Haller, 1996). For example, although the ADA is a civil rights law dealing with a myriad issues, especially employment discrimination against people with disabilities, the issue of architectural access was cited most often as the reason for the ADA in the media stories. This finding can definitely be tied to the business concerns about the ADA because architectural access had the potential to be the most costly to business and local governments. It should be noted that in the ADA stories, the federal government sources and local government sources were typically on different 'sides'.

Almost 20 years after the ADA became legislation, the US disability rights community decided to embrace media as a way to get the general public to understand disability in the political realm, that is, to better comprehend what laws like the ADA might mean for all Americans. Organizations like the US Disability Rights Education and Defense Fund (2015), which openly reported its lobbyists did not want to spend time trying to educate journalists about the ADA, started its own media initiative in 2008, and another organization, the National Center on Disability and Journalism (NCDJ), was founded in 1998 'as the Disability Media Project to raise awareness of how the news media can better cover people with disabilities' (NCDJ website, 2015).

Interestingly, 2008 was a pivotal year for the ADA because the ADA Amendments Act (ADAAA) was passed, and after President Barack Obama was elected, he revised and strengthened ADA regulations in 2010. 'Importantly, the ADAAA restores the original promise of the ADA - that individuals with disabilities, who are willing and able to work, should be able to do so free from discrimination' (ACLU, 2008).

Because of the ADAAA and strengthened regulations, the federal government has more vigorously enforced the ADA, which has led to more news media 
coverage. Daily Google Alerts tracking the news coverage since 2008 have found 6-10 news stories or opinion pieces per day about the legislation. Stories cover a variety of disability legal issues under the ADA, everything from Florida enacting legislation to punish nondisabled people who try to pass off their pets as service dogs (Cotterell, 2015) to all of a school district's playgrounds in an Oklahoma town being made accessible (Gust, 2015).

The ADA has been held up as a model of good disability rights law in many countries around the world. According to Heumann, in many countries,

people look to the ADA as a touchstone of what legislation should look like, particularly in the area of anti-discrimination. They look to the US as a country that has greater enforcement and mechanisms where there's a clear legislative commitment to laws that have teeth. So the ADA and other pieces of legislation in America are seen as being very important to disabled people around the world. (Tegler, 2015, p. 157)

And with the ease of following news worldwide via the Internet, anyone can read stories about what is happening with disability rights legislation in the USA.

The 25-year-old ADA's message is simple - that people with disabilities deserve the same rights as those without disabilities - and the US news media more often than not now embraces some of that message. Kudlick says the ADA

changed the equation from being accommodation for individuals out of generosity to a situation where everyone could have access whether or not we know they need it. It became a rights-based issue, and that affects your social attitude. If you think access is your right versus a handout, you're going to approach everything differently. (Tegler, 2015, p. 152)

This is called the social aspect of the ADA: 'The manner in which American society views people with disabilities and the way people with disabilities see themselves has been positively influenced by the ADA' (Tegler, 2015, p. 152). That social aspect is intertwined with news media coverage of disability rights legislation and the way the media can influence public opinion.

\section{National Disability Insurance Scheme}

The NDIS in Australia grew from a seed of inspiration planted at a national summit called by then Prime Minister Kevin Rudd in 2008. The 2020 Summit, as it was called, was held in Parliament House and brought together 1,000 of Australia's 'best and brightest' representatives from across the country to take part in, what was essentially, a massive, multi-day, town hall meeting. The prime minister had challenged the representatives to create a list of priority issues for the country. This process, literally, involved the nation's leaders, who had been grouped in areas of interest/expertise, sitting in allocated rooms, scribbling lists of ideas on whiteboards and, over a matter of days, trimming their respective group's lists down to four priority issues. The NDIS was one of the ideas raised. 
The idea flowed from the 'communities and families' group, and was raised by the philanthropist Bruce Bonyhady. It was presented as a means to 'shift from the current crisis-driven welfare system to a planned and fully funded National Disability Insurance Scheme that would underwrite sustained significant, longterm improvements in meeting the needs of people with disabilities and their families' (Bonyhady, 2008). Significantly, the NDIS was also presented as progressive and as a productivity measure. In 2011, the Australian Productivity Commission presented its report on disability service provision in Australia and the implications of an NDIS. The Commission had been charged with assessing a scheme which would, among other things, provide 'long-term essential care and support for eligible people with a severe or profound disability, on an entitlement basis and taking into account the desired outcomes for each person over a lifetime' (Australian Government Productivity Commission, 2011). The Commission concluded that the NDIS would have substantial economic impact over the long term as people with mild to profound disabilities achieved employment, and their family members also returned to, or were able to enter, the workforce. It stated: 'Under a reasonable scenario, the Commission estimates that there could be an additional employment growth of 220,000 by 2050 ... its benefits would significantly exceed the additional costs of the scheme' (Australian Government Productivity Commission, 2011).

In 2013, the Australian government announced funding for seven NDIS launch sites across the country, and included in its forward budget estimates fund- ing for the complete rollout of the scheme by 2019. The NDIS funding commit- ment was delivered inside the whirlpool of a looming federal election campaign in 2013. Then Prime Minister Julia Gillard and Opposition Leader Tony Abbott had publicly declared the NDIS was too important an issue for it to become a 'political football'. Both leaders were repeatedly called on by people with disability, advocacy groups and the wider community to 'make the NDIS real'. The campaign was spearheaded by the Every Australian Counts campaign, led by former New South Wales (NSW) state minister John Della Bosca. Every Australian Counts championed the NDIS as a productivity measure for the country; a way in which people with disability could be supported to be productive and contributory members of the community, and, in so doing, also provide tens of thousands of family members and carers the opportunity to join or rejoin the workforce.

Every Australian Counts is a people's campaign sweeping across the country, demanding the successful roll out of a National Disability Insurance Scheme (NDIS), as recommended by the Productivity Commission.... The NDIS will be a modern, personcentred support system, helping hundreds of thousands of Australians with disability and their families to have the opportunity to participate actively in their communities by providing targeted supports aligned to need. (NDS, 2014)

\section{The Role of the Media}

The Australian news media had an important role to play in how the NDIS, from grain of inspiration to inception, was presented and received. While there was 
widespread support for the scheme, represented in the public opinion polls, it also had a significant price tag-estimates at the time putting it in the realm of A\$ 6 billion a year.

While the bipartisan support for the scheme that was witnessed on 14 March 2013 provided a rare moment of unity between government and opposition, did the NDIS funding commitment come with the assistance of, or despite, news media coverage of the scheme? Did the news media present the NDIS as progressive and productivity based, as the Productivity Commission has declared it to be?

Clogston (1990, 1993) and Haller (1995) provide us with a tool to quantify media representation of people with disability. Their media models of disability divide coverage into the traditional and progressive categories. The eight media models of disability are, as cited in Power (2007):

1. Traditional: the 'medical' model, in which disability is presented as an illness or malfunction;

2. Traditional: the 'social pathology' model [in which] disabled people are presented as disadvantaged and must look to the state or society for economic support, which is considered a gift, not a right;

3. Traditional: the 'supercrip' model [in] which the disabled person is portrayed as deviant because of 'superhuman feats', or as 'special' because he or she lives a regular life 'in spite of' their disability;

4. Traditional: the 'business' model, in which disabled people and their accessibility to society are presented as costly to society in general, and to businesses especially;

5. Progressive: the 'minority/civil rights' model, in which disabled people are seen as members of a disability community, which has legitimate civil rights and grievances;

6. Progressive: the 'legal' model, in which disabled people are presented as having legal rights and possibly a need to sue to halt discrimination;

7. Progressive: the 'cultural pluralism' model, in which people with disabilities are seen as multi-faceted and their disabilities do not receive undue attention;

8. Progressive: the 'consumer' model, in which disabled people are presented as an untapped consumer group and making society accessible could be profitable to business and society.

To gain an understanding of the media representation of disability in the context of the NDIS, the researchers have applied the models to newspaper articles published between 2008 (the 2020 Summit) and August 2013 (the passing of the NDIS funding legislation).

To that end, the researchers analyzed newspaper articles drawn from Australian newspapers. The newspapers were selected by circulation and geography. Nine newspapers were analyzed, namely, The Australian (national), The Canberra Times (Australian Capital Territory [ACT]), The Daily Telegraph (NSW), The Herald Sun (Victoria), The Courier Mail (Queensland), The Northern Territory Times (Northern Territory [NT]), The West Australian (Western Australia), The Advertiser (South Australia) and The Hobart Mercury (Tasmania).

The analysis included the compilation of descriptive data through a database search (Factiva) of the nine newspapers. The researchers used the media models of disability to categorize articles that mentioned search terms 'NDIS', 'National 
Disability Insurance Scheme' and/or 'DisabilityCare Australia'. The federal government in 2013 renamed the scheme 'DisabilityCare Australia'.

\section{Findings}

A Factiva search of the terms 'National Disability Insurance Scheme', 'NDIS' and/ or 'DisabilityCare Australia' returned 1,731 articles. For the purposes of this article, the researchers were interested to see how many of the articles represented people with disability progressively versus those that relied on traditional media models of disability. This is a significant inquiry, as the NDIS, according to leading advocates, including the Every Australian Counts campaign, was a progressive initiative. It was about including people with disability, and, importantly, providing them with the resources they needed to be a productive member of the society.

The analysis revealed just under three-quarters $(1,277$ or 74 per cent) of the identified articles were not specifically about the NDIS, and were eliminated from any further analysis (Figure 1). While these articles contained one or more of the search terms, they were not considered to relate specifically to the NDIS. Articles were also rejected when, for example, they passingly mentioned the NDIS in a broader discussion of government endeavours or were simply included in lists. These articles did not provide sufficient context to be able to apply the models and, therefore, categorize them as either traditional or progressive representations of disability.

A total of 455 articles (26 per cent) were categorized as being specifically about the NDIS. The content analysis revealed that the vast majority (325 or 74 per cent) of the articles were presented within the traditional media models of disability. Just over a quarter of the articles (130 or 26 per cent) were classified as presenting progressive representations of people with disability in the context of coverage of the NDIS (Figure 2).

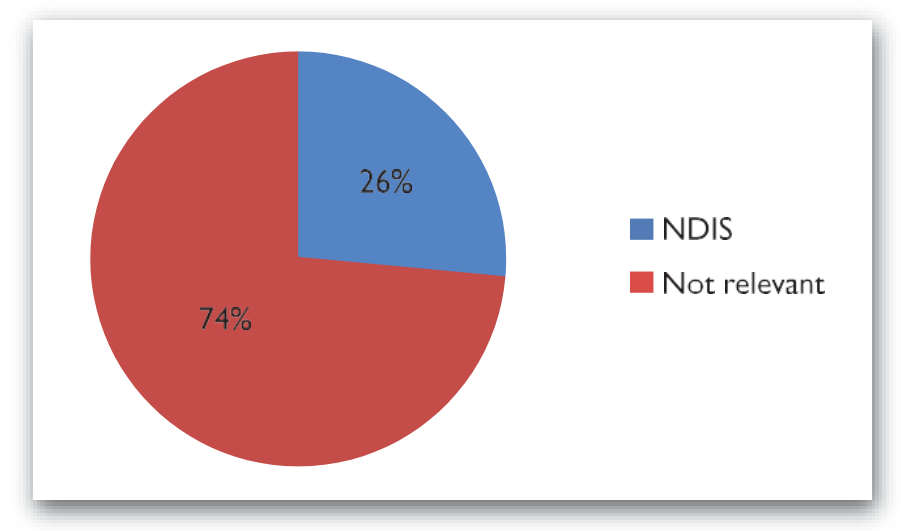

Figure 1. Overall

Source: Burns (2015). 


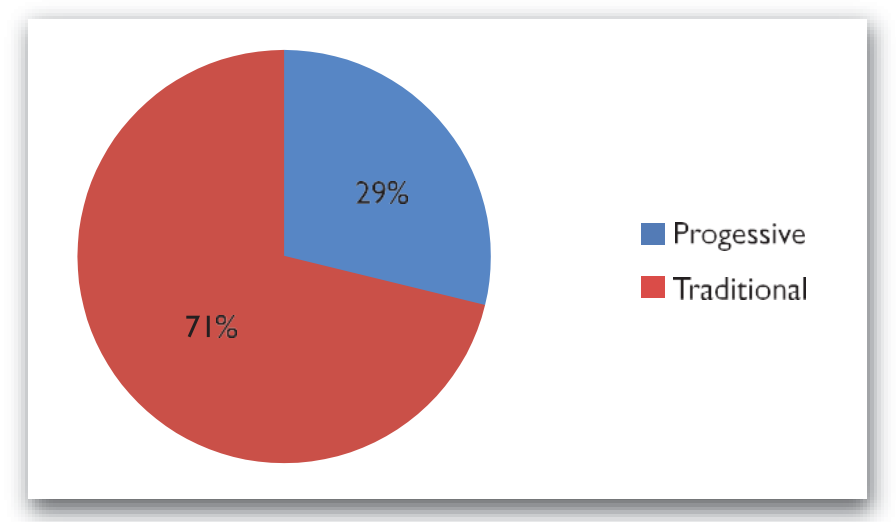

Figure 2. Progress vs Traditional Media Models of Disability

Source: Burns (2015).

Of the articles considered traditional, the social pathology model of disability was dominant. Of the 325 traditional articles, 306 (94 per cent) were considered to be best represented by the social pathology model. Of the remaining traditional models, 16 (5 per cent) were considered medical, 3 ( 1 per cent) were supercrip and none were categorized under the business model (Figure 3).

Far fewer articles were categorized as progressive, but in contrast to the traditional findings, there was a greater spread of articles within the progressive media models of disability.

When broken down, 74 of the progressive articles (57 per cent) were categorized under the minority/civil rights model, 49 (38 per cent) under the consumer model, 4 (3 per cent) were cultural pluralism and 3 ( 2 per cent) were considered legal (Figure 4).

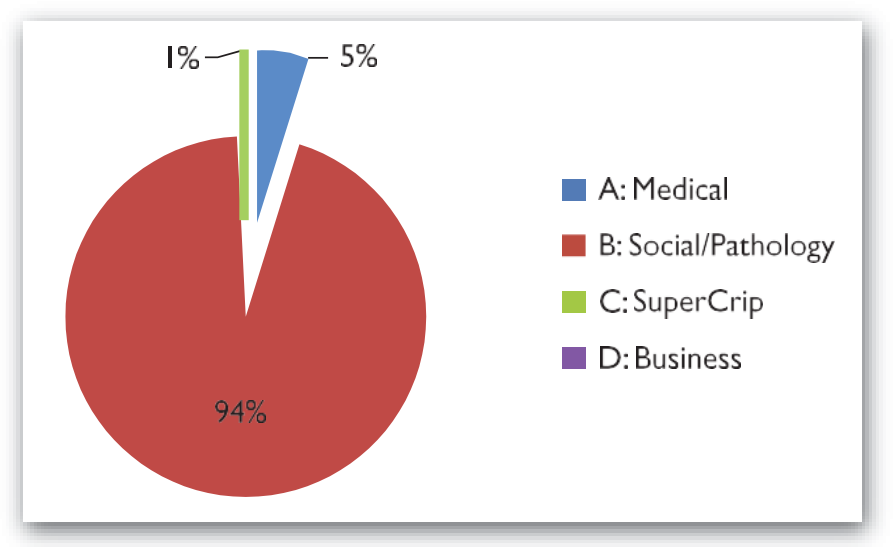

Figure 3. Traditional Models of Disability

Source: Burns (2015). 


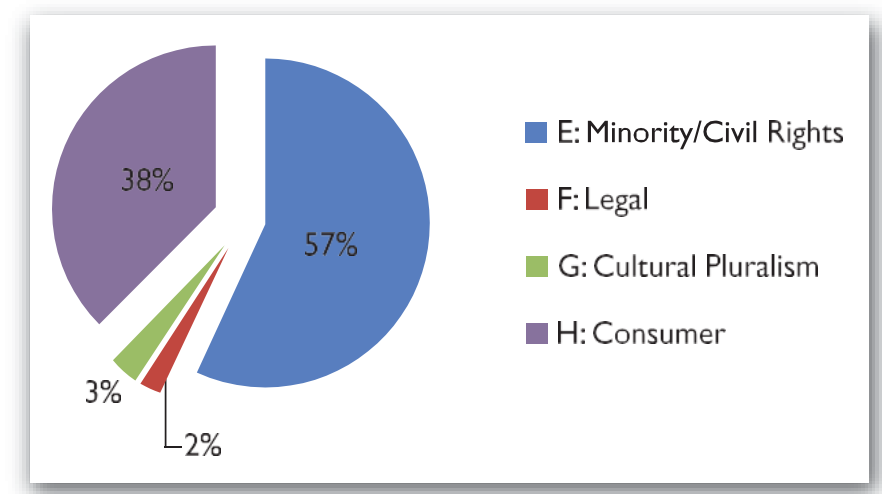

Figure 4. Progressive Models of Disability

Source: Burns (2015).

The findings revealed three significant aspects of the coverage of the NDIS. The NDIS, while considered a significant public policy issue, received limited indepth coverage across the years between 2008 and 2013. Of the 1,731 articles identified as mentioning the National Disability Insurance Scheme, NDIS and/or DisabilityCare Australia, just over a quarter gave it sufficient treatment that it could be categorized within a specific media model. The vast majority of instances where the search terms were present in articles could be considered 'passing mentions'.

The second significant finding is that the strong majority of articles specifically dedicated to the NDIS were categorized as being 'traditional' representations of disability. And, finally, the overwhelming traditional representation of people with disability in the newspaper articles was categorized as social pathology, where 'people with disability are presented as disadvantaged and must look to the state or society for economic support, which is considered a gift, not a right' (Clogston, 1990).

It is most significant to note the disparity between the aspirations of proponents of the NDIS that it be a progressive and productivity-driven public policy initiative, and the vastly traditional representations of disability found within media coverage of the NDIS. The research finds limited coverage of the scheme in the country's highest circulating newspapers, and, even when there was coverage, it was comprehensively traditional, with the aspirations of progressiveness seeded in the initiative largely kept out of the media frame. While answering the question, at least in part, of how the NDIS was covered in the print news, the findings serve to create more questions - most pressingly, 'Why does the news media continue to choose, if not need, to represent people with disability as objects of pity?' The continued use of familiar frames or models of disability in the media in the coverage of the NDIS is contrary to the Productivity Commission report that claimed the NDIS would 'also provide information to people, and help break down stereotypes'. It is also in direct contrast to the benefits stated by the man who first touted the scheme, Bruce Bonyhady: 'The vision of the NDIS is simple 
and powerful: to maximize people's independence and social and economic participation' (Bonyhady, 2014).

\section{Conclusion}

The ADA and the NDIS are landmark political and public policy initiatives. The role the news media has played in their evolution and implementation should not be underestimated. As Ellis and Goggin state: 'Media not only matter, in their pervasiveness and power; they play an important role in the power relations and shaping of disability' (2015, p. 14).

The passing of a quarter of a century has allowed the ADA, its impact on people with disability and the role the media eventually played in facilitating greater general public understanding of the policy (and the ADAAA) and of people with disability to be considered through the lens of experience. The ADA was driven by people with disability who, as Gusfield (1981) espoused, took

'ownership' of disability discrimination as a public problem. Americans with disabilities focused attention on government and policy makers in their efforts to see the ADA established. A conscious decision was made by people with disability not to engage with the news media, based on the fear it would continue to use stereotypes to represent them and the problems they faced. In the end, the decision proved to be mistaken, as the news media filled the void created by a lack of 'disability voices' by those less enamoured with the ADA, those who saw it as a cost - business and local government. With the evolution of the ADAAA, disability activists recognized the importance of the news media in encouraging the greater public to take ownership of disability discrimination as their problem, too.

Public ownership also seems to be at the heart of the relatively expedient process by which the NDIS was formulated, funded and launched in Australia. This public ownership, however, would appear to have been constructed on a platform of traditional representations of people with disability in the news media. Despite a Productivity Commission report that presented the scheme as a progressive and productive initiative that would benefit the wider community and not just people with disability, newspapers across the country overwhelmingly used traditional models of disability to represent disability in their coverage of the NDIS. Most often, people with disability were presented as 'disadvantaged and must look to the state or society for economic support, which is considered a gift not a right'. It could, therefore, be argued that public ownership of the NDIS coupled with a desire by politicians to avoid turning the scheme into a 'political football' was underpinned by a news media that was unaware, unwilling and/or unable to look beyond the stereotypical and traditional media models of disability when covering this socially progressive and economically productive public policy.

Finally, we hope that analyzing news media as it covers disability politics and legislation will become an endeavour of researchers in other countries. Because of numerous barriers to participation in many countries, people with disabilities may only be known to the larger society through media coverage. Many more 
countries are making efforts to give greater rights to people with disabilities because they have put their signatures on the UN Convention on the Rights of Persons with Disabilities (CRPD) and that means more coverage of disability issues flowing into the news. For example, The Jakarta Post in Indonesia reported on how the Indonesian legal system is failing women with disabilities 'as their testimonies were often deemed unreliable as the necessary interpreters were not provided during questioning, hampering their access to justice' (The Jakarta Post, 2015 June 30). This kind of disability rights-focused news coverage is important to a society's understanding of disability; thus, it is crucial that more research be done to investigate how political issues regarding people with disabilities play out in a country's news media.

\section{Discussion: Lessons for Students, Journalists and Academics}

The research also has implications for journalism students, journalists and journalism academics. It demonstrates the significance of news media representation of disability, and the capacity of journalists and news media to shape how the community sees them.

It provides a cause to examine the inclusion of diversity studies, specifically disability studies, in journalism education. The study shows there are progressive representations in news media, and, as has been the case in the US post the implementation of the ADA, there is impact associated, if not directly assigned, to fair and accurate representation of disability and people with disability. Journalism educators are well placed to raise awareness of diversity in society and to draw their students' attention to the role the news media plays in challenging and/or embedding stereotypes and traditional media representations of vulnerable members of the community.

Likewise, this study shows journalism academics are positioned to shine an exploratory light on the work of news journalists - from junior to veteran - and to carry out and present research that challenges the status quo. Journalism academics have a responsibility to critically examine journalism practice and to highlight its strengths but, more importantly, address its weaknesses; this article has done both. However, as the exploration of the NDIS has revealed, there is still work to be done when it comes to news media representation of disability and that work needs to done in classroom and the newsroom.

\section{References}

American Civil Liberties Union (ACLU) (2008, September 17). ACLU praises house passage of ADA Amendments Act of 2008. ACLU website [Press release]. Retrieved 1 June 2015, from https://www.aclu.org/news/aclu-praises-house-passage-adaamendments-act-2008?redirect=organization-news-and-highlights/aclu-praises-housepassage-ada-amendments-act-2008

Australian Government Productivity Commission. (2011). Disability care and support: Productivity commission report overview and recommendations. Retrieved 4 June 2015, 
from http://www.pc.gov.au/inquiries/completed/disability-support/report/disabilitysupport-overview-booklet.pdf

Bonyhady, B. (2008). Adequate support for people with disability. Perspectives website. Retrieved 3 June 2015, from http://www.futureleaders.com.au/book_chapters/pdf/ Perspectives/Bruce_Bonyhady.pdf

_. (2014). Bruce Bonyhady speech: St Laurence National Conference. NDIS website. Retrieved from http://www.ndis.gov.au/document/889

Burns, S. (2011). An exploration of the adherence of journalists in Australia to established media guidelines on the depiction of people with disability. Master of Arts - Research thesis, University of Wollongong. Faculty of Arts, University of Wollongong.

Clogston, J.S. (1990). Disability coverage in 16 newspapers. Louisville: Advocado Press.

- (1993). Changes in coverage patterns of disability issues in three major American newspapers 1976-1991. Kansas City, MO: Association of Education in Journalism and Mass Communications.

Croteau, D., \& Hoynes, W. (2003). Media society: Industries, images, and audiences (3rd ed.). Thousand Oaks: Pine Forge Press.

Collins, C. (2015). 'The Capitol crawl', equal access, equal opportunities. 25th anniversary of the Americans with disabilities act (pp. 48-57). Tampa, FL: Faircount Media.

Cotterell, B. (2015). Florida cracks down on people posing pets as service animals. Reuters. Retrieved 3 June 2015, from http://www.businessinsider.com/r-florida-cracks-downon-people-posing-pets-as-service-animals-2015-6

Disability Rights Education and Defense Fund. Media and Disability. (2015). DREDF website. Retrieved 6 June 2015, from http://dredf.org/media-disability/

Ellis, K., \& Goggin, G. (2015). Disability and the media. UK: Palgrave.

Gans, H. (1980). Deciding what's news: A study of CBS Evening News, NBC Nightly News, Newsweek and Time. New York: Vintage.

Gitlin, T. (1980). The whole world is watching. Berkeley, CA: University of California Press.

Gusfield, J. (1981). The culture of public problems. Chicago: University of Chicago Press. Gust, S. (2015). School playgrounds in Edmond being made accessible for disabled children. The Oklahoman. Retrieved 3 July 2015, from http://newsok.com/schoolplaygrounds-in-edmond-being-made-accessible-for-disabled-children/article/5430238

Haller, B. (1995). Disability rights on the public agenda: News coverage of the Americans with Disabilities Act. Unpublished Doctoral dissertation, Temple University, Philadelphia, PA.

- (1996). Balancing acts: Government, business, and disability sources in news representations of the ADA. Paper Presented at the Association for Education in Journalism and Mass Communication annual meeting, Anaheim, CA.

(1999). When they limp, they lead? News representations and the hierarchy of disability images. In Dawn Braithwaite \& Teresa Thompson (Eds), Handbook of communication and people with disabilities: Research and application (pp. 225-237). Mahwah, NJ: Lawrence Erlbaum.

- (2010). Representing disability in an ableist world: Essays on mass media.

Louisville, KY: Advocado Press.

International Labour Organization (2015). Reporting on disability. Guidelines for the media. Switzerland: ILO Press. Retrieved 5 June 2015, from http://www.ilo.org/wcmsp5/groups/ public/---ed_emp/---ifp_skills/documents/publication/wcms_127002.pdf

Johnson, M. (1998). The consequences of silence. The Ragged Edge, November/December. Retrieved 5 June 2015, from http://www.raggededgemagazine.com/1198/c1198tme. $\mathrm{htm}$ 
McCombs, M. (1992). Explorers and surveyors: Expanding strategies for agenda-setting research. Journalism Quarterly, 69(4), 813-824.

McCombs, M., \& Shaw, D. (1972). The agenda-setting function of the press. Public Opinion Quarterly, 36(2), 176-187.

McQuail, D. (1989). Mass communication theory. London: SAGE Publications.

National Center on Disability and Journalism (NCDJ) (2015). About NCDJ. NCDJ website. Retrieved 18 June 2015, from http://ncdj.org/about/

National Disability Services (NDS) (2014). Every Australian Counts Campaign (EAC) community educator. NDS website. Retrieved 5 June 2015, from http://www.nds.org. au/jobs/article/623

Olien, C.N., Tichenor, P.J., \& Donohue, G.A. (1989). Media and protest. In Larissa Grunig (Ed), Monographs in environmental education and environmental studies (p. 24). Troy, $\mathrm{OH}$ : North American Association for EnvironmentalEducation.

Power, D. (2007). Disability in the news comunicacion \& discapacidades: Actas de Foro Internacional [Communication \& disability: Proceedings of an international forum]. Santiago de Compestela: Observatorio do Galego dos Medios [Galician Media Monitor] Universidade de Santiago da Compostela. Observatorio Galego dos Media [Galician Media Monitor].

Rosenthal, E., \& Kanter, A. (2002). The right to community integration: Protections under United States and international law. Berkeley, CA: DREDF. Retrieved 20 June 2015, from http://dredf.org/international/paper_r-k.html

Ryan, M., \& Owen, D. (1976). A content analysis of metropolitan newspaper coverage of social issues. Journalism Quarterly, 53(1), 634-640, 671.

. (1977). An accuracy survey of metropolitan newspaper coverage of social issues. Journalism Quarterly, 54, 27-32.

Shapiro, J. (1993). Disability policy and the media: A stealth civil rights movement bypasses the press and defies conventional wisdom. In Sara Watson \& David Pfeiffer (Eds), Disability policy as an emerging field of mainstream public policy research and pedagogy: A symposium edition of the policy studies journal (pp. 123-132). New York: Broadway Books.

- (1994). No pity: People with disabilities forging a new civil rights movement. NY: Broadway Books.

Tanner, S. (1990). Parochialism, politics, and the Tasmanian press: A study in the politics of journalism. Unpublished dissertation, Department of Political Science. Hobart, University of Tasmania.

Tegler, J. (2015). 'Disability in the social context', equal access, equal opportunities. 25th anniversary of the Americans with disabilities act (pp. 152-159). Tampa, FA: Faircount Media.

The Jakarta Post (2015, June 30). Legal system failing women with disabilities. The Jakarta Post. Retrieved 3 July 2015, from http://www.thejakartapost.com/news/2015/06/30/ legal-system-failing-women-with-disabilities.html

Tichenor, P.J., Donohue, G.A., \& Olien, C.N. (1980). Community conflict and the press. Beverly Hills: SAGE.

U.S. Department of Justice (US DOJ) (2010a). President Obama announces revised ADA regulations. US DOJ website [Press release]. Retrieved from http://www.justice.gov/ opa/blog/president-obama-announces-revised-ada-regulations

U.S. Department of Justice (US DOJ) (2010b). The Americans with disabilities act of 1990 and revised ADA regulations implementing title II and title III. US DOJ website. Retrieved from http://www.ada.gov/2010_regs.htm 


\section{Authors' bio-sketch}

Shawn Burns is a Journalism lecturer at the University of Wollongong in Wollongong, NSW, Australia. He researches the representation of people with disability in news media, newsroom practice and pedagogy.

Beth Haller, Ph.D., is Professor of Journalism/New Media at Towson University in Maryland, USA. She is the author of Representing Disability in an Ableist World: Essays on Mass Media (Advocado Press, 2010) and Byline of Hope: Collected Newspaper and Magazine Writings of Helen Keller (Advocado Press, 2015), as well as numerous academic articles and book chapters. 